\title{
Variability of Rice Production in Monsoon Asia
}

\author{
Koki Homma*, Tatsuhiko Shiraiwa and Takeshi Horie
}

Graduate School of Agriculture, Kyoto University, Kyoto 606-8502, Japan

\begin{abstract}
Since ancient times, rice has been a staple food in monsoon Asia, an area in Asia which is strongly affected by monsoon activity and home to a dense population comprising many millions of individuals. Since rice is usually produced by a given country to feed its own population, production variability is commonly analysed on a country-by-country basis. However, recent globalisation and the frequency of disasters suggest that production variability, especially poor production, affects not only the producing country but also nations in the same region. In this research effort we analysed the variability in rice production in monsoon Asia and showed that large depletions in production derive primarily from production trends in India. Interestingly, India tended to undergo bumper years when China experienced lean years. If bumper years in India are associated with lean years in China, successful production in India can cushion the blow of poor production in China. We found no causal connection between rice production in India and rice production in China. Therefore, we would advocate more accurate analyses in the future that use approaches from disciplines such as climatology, hydrology and agronomy.
\end{abstract}

Keywords: China, disaster, ENSO, India, monsoon index.

\section{INTRODUCTION}

Rice is a staple food from ancient in monsoon Asia, and widely consumed in the world in the present. Since rice is mostly produced self sufficiently, its production variability is commonly analyzed based on a country (e.g. [1-3]). However, the international trade of rice has been increasing gradually from 11 million tonnes (2.2\% of total global production) in 1990 to 29 million tonnes (4.4\%) in 2006 [4]. China and Indonesia are predicted to be huge importers in the future, suggesting that the level of trade will still increase further. Moreover, extremely poor production such as that experienced by Japan in 1993 sometimes necessitates emergency imports, which increases the price of the desired product on the world market. Recently, international speculative investments have complicated the market, causing an increase in the international price of rice in 2008. These developments indicate that rice is still produced largely by individual countries to feed their own inhabitants, but that this trend is changing. Dawe [5] summarized the price increase as rice crisis, and recommended to prepare to prevent the next crisis.

This study aimed to reveal the variability of rice production in monsoon Asia. For the purpose, we especially focused on lean years. In order to analyse relationship between the production variability and climate, El Niño-Southern Oscillation (ENSO) index [6] and several monsoon indexes were used.

*Address correspondence to this author at the Graduate School of Agriculture, Kyoto University, Kyoto 606-8502, Japan; Tel: 81-75-753-6042;

Fax 81-75-753-6065; E-mail: homma@kais.kyoto-u.ac.jp

\section{MATERIALS AND METHODS}

In this study, monsoon Asia was defined to include 20 countries (Table 1). Production amount, harvested area and yield of rice for each country from 1961 to 2010 were obtained from FAOSTTAT [4]. We calculated 4 parameters from the data for our analysis: deviation from 5-year running averages; deviation rate against 5-year running averages; mean absolute deviation rate (MADR); and coefficient of variance, which is determined by dividing standard deviation for a 5 -year period by the 5-year running average.

The classification of ENSO phases was based on an index (ENSO index) from the Japan Meteorological Agency [6]. This index is a 5-month running average of spatially averaged sea surface temperature (SST) anomalies throughout the tropical Pacific: $5^{\circ} \mathrm{S}$ to $5^{\circ} \mathrm{N}$, and $150^{\circ}$ to $90^{\circ} \mathrm{W}$ (NINO. 3). The ENSO years were categorised as El Niño when the index values exceeded $0.5{ }^{\circ} \mathrm{C}$ for 6 consecutive months in a given year and as La Niña when the index values fell below $-0.5^{\circ} \mathrm{C}$ for 6 consecutive months in a given year. In addition to ENSO classifications, five monsoon indexes were also used in this study: the Webster and Yang monsoon Index (WYI [7]), the Indian summer Monsoon Index (IMI [8]) and the Western North Pacific Monsoon Index (WNPMI [9]) were obtained from the International Pacific Research Center [10]; the East Asian Summer Monsoon Index (EASMI [11]) and the South Asian Summer Monsoon Index (SASMI [12]) was obtained from the Chinese Academy of Science [13]; and the Meridional Thermal Gradient Index (MTGI $[14,15])$ was obtained from the University of Toyama, Japan [16].

In order to analyse relationship between rice production and precipitation in China, we selected the top-5 years as the bumper years on the basis of deviation rate against 5-year 
Table 1. List of countries analysed in this study, together with their 5-year-average harvested area $\left(10^{3}\right.$ ha) and production metrics $\left(10^{3}\right.$ t) in 1963 and 2008; and the mean absolute deviation rate from 1963 to 2008 (MADR, \%).

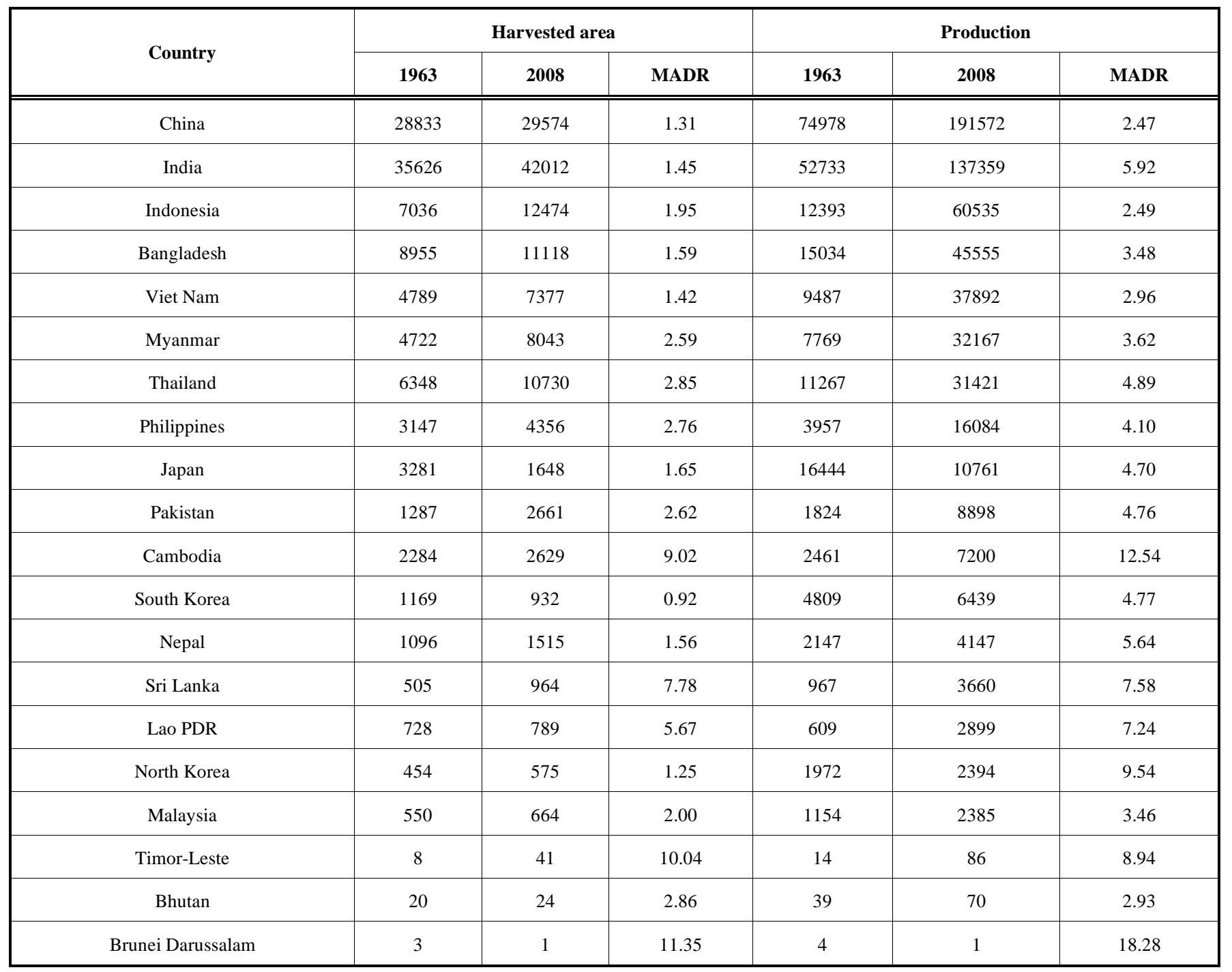

running average: 1966, 1970, 1979, 1984 and 1990; and selected the bottom-5 years as the lean year: 1969, 1981, 1988, 1994 and 2003. Data for precipitation in China were obtained from the Global Historical Climatology Network at the National Climatic Data Center, USA [17]. The data for 39 stations, with negligible missing data, were used for our analysis. The stations widely distributed in China (Fig. 4). The frequency of precipitation anomalies was obtained on the basis of the 47-year average from 1961 to 2007.

Statistic analysis was conducted using SAS Version 9.1 (SAS Institute Inc., USA).

\section{RESULTS AND DISCUSSION}

\subsection{Features of Rice Production}

Rice production in monsoon Asia increased from 198 million tonnes in 1961 to 603 million tonnes in 2010 (Fig. 1a). The increase in production $(+205 \%$ increase $)$ is significantly dependent on both that in yield $\left(2.0\right.$ to $4.8 \mathrm{t} \mathrm{ha}^{-1}$ : $+140 \%$ increase) and that in harvested area (98 to 124 mil- lion ha: $+27 \%$ increase). The coefficient of variance showed that production variability decreased drastically from 1982 to 1992 but increased gradually after this period (Fig. 1b). Yield variability peaked in 1982 but then decreased until 2000 and has recently tended to increase. The lowest levels of variability in the harvested area were observed in 1992, with an increasing trend since that time. Our findings indicate that the decreased variability in production observed from the 1960s through the 1980s was associated with a similar trend in yield, and that the recent increased variability in production was caused primarily by the variability in harvested area and secondarily by the variability in yield. This phenomenon may be due to the expansion of cultivation to unfavourable areas [18] or to an increase in the number of farmers who abandon crops in unfavourable weather years $[19,20]$. These factors may increase the sensitivity of rice production to climate change and may decrease food security.

Mean absolute deviation rate (MADR) of rice production varies from 2.47 to 18.28 among countries (Table 1). Brunei, Cambodia, Timor-Leste and North Korea show larger variability, which may be derived from domestic affairs. China 


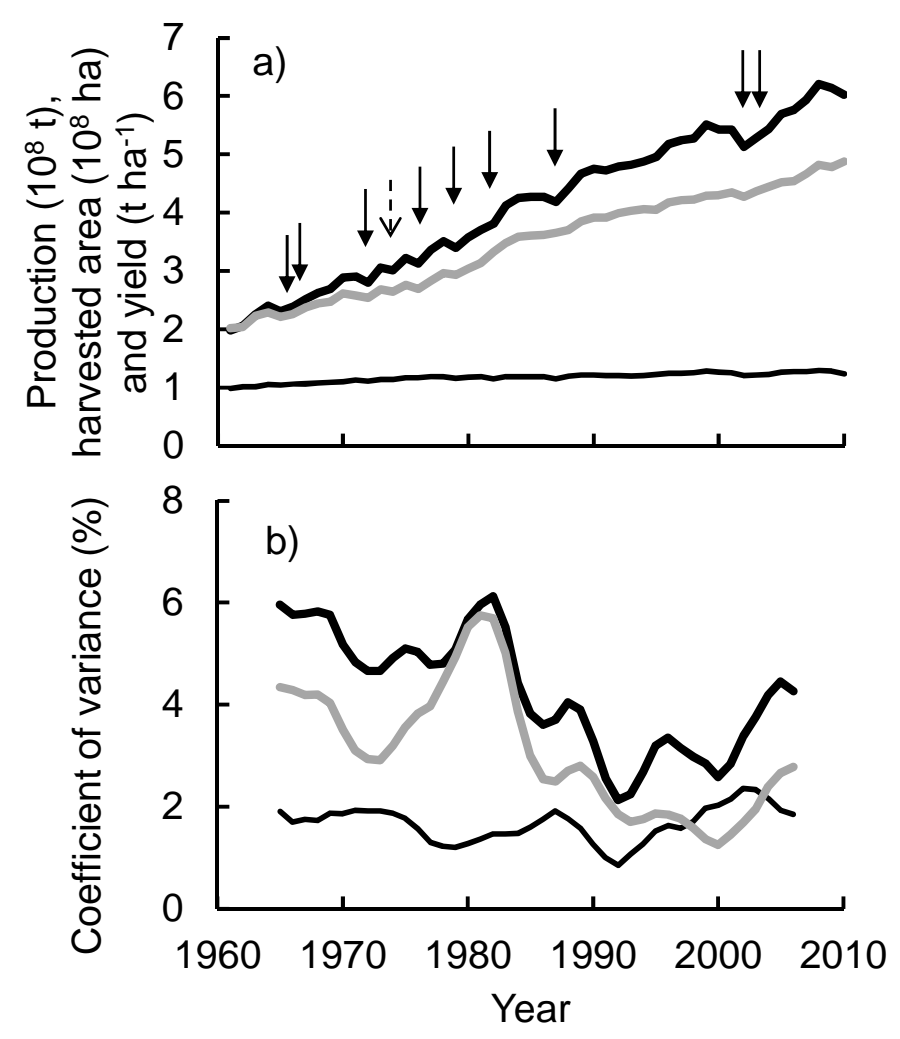

Fig. (1a). Trends in rice production (bold black), yield (bold gray) and harvested area (thin black) in monsoon Asia. Arrows show years when the production decreased more than $2 \%$ as compared to the 5-year average (lean year: deviation rate <-2\%). Although the deviation rate in 1974 was $-1.2 \%$, this year was also selected as a lean year based on this figure (dashed arrow). (b) Trend in 5-year running average of coefficients of variance of rice production (bold black), yield (bold gray) and harvested area (thin black) in monsoon Asia.

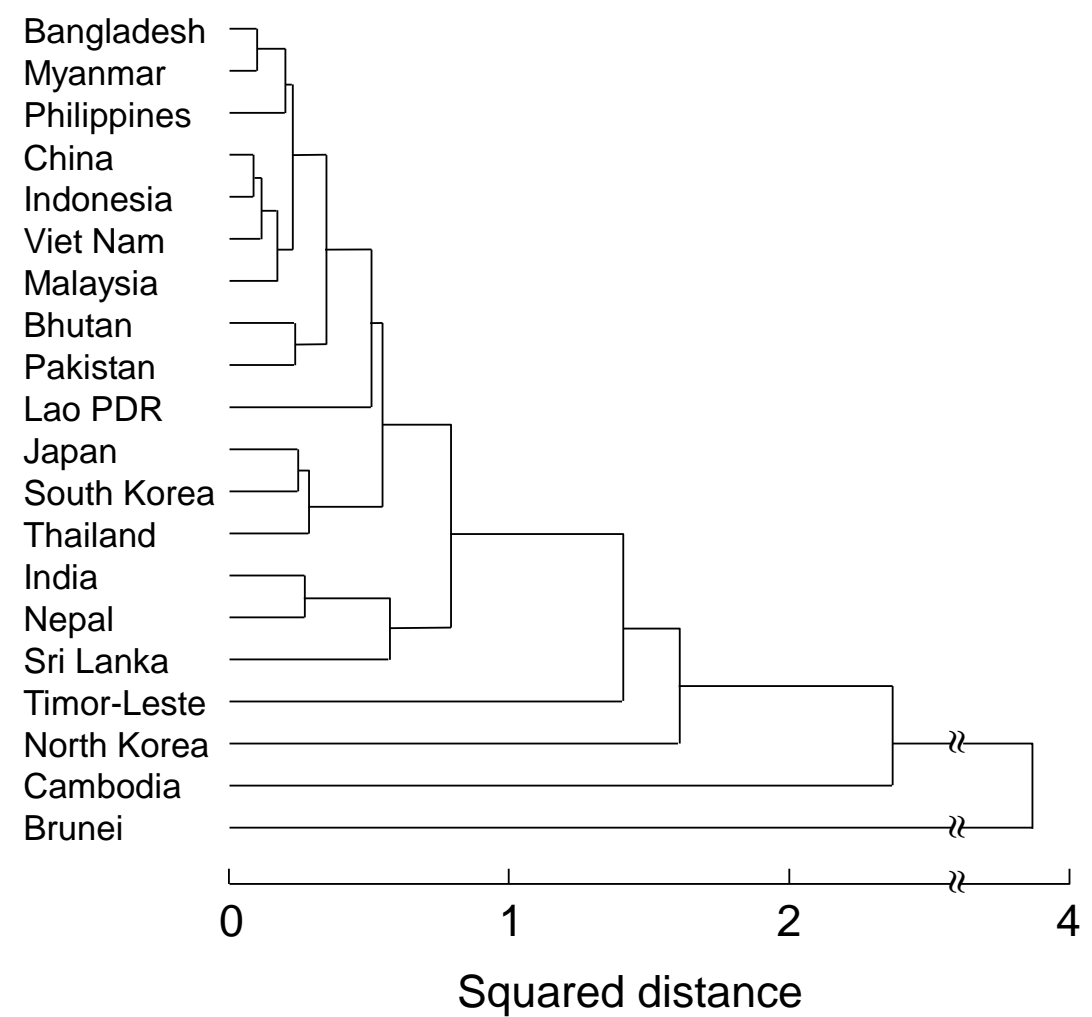

Fig. (2). Country groups clustered by Ward method. The cluster analysis was applied to deviation rate of rice production in each country from 1963 to 2008 . 
Table 2. Deviations of rice production, yield and harvested areas in monsoon Asia during the lean years. The listed countries are the three most important with regard to causing the lean harvest.

\begin{tabular}{|c|c|c|c|c|c|c|c|c|c|c|c|c|c|}
\hline \multirow{3}{*}{ Year } & \multicolumn{3}{|c|}{ Deviation rate $(\%)$} & \multirow{2}{*}{$\begin{array}{c}\begin{array}{c}\text { Monsoon } \\
\text { Asia }\end{array} \\
\text { Deviation }\end{array}$} & \multicolumn{3}{|c|}{ 1st } & \multicolumn{3}{|c|}{ 2nd } & \multicolumn{3}{|c|}{ 3rd } \\
\hline & & & Harvested & & Country & Deviation & $\begin{array}{c}\text { Rate } \\
(\%)\end{array}$ & Country & Deviation & $\begin{array}{c}\text { Rate } \\
(\%)\end{array}$ & Country & Deviation & $\begin{array}{c}\text { Rate } \\
(\%)\end{array}$ \\
\hline & & & Area & $\left(10^{6} t\right)(A)$ & & $\left(10^{6} t\right)(B)$ & (B/A) & & $\left(10^{6} t\right)(B)$ & $(\mathbf{B} / \mathbf{A})$ & & $\begin{array}{c}\left(10^{6} t\right) \\
(B)\end{array}$ & (B/A) \\
\hline 1965 & -3.0 & -2.7 & -0.2 & -7.0 & India & -6.6 & 94.1 & Japan & -0.8 & 11.0 & Thailand & -0.8 & 10.9 \\
\hline 1966 & -2.5 & -2.5 & -0.1 & -6.2 & India & -7.7 & 122.9 & Bangladesh & -1.6 & 25.1 & Myanmar & -1.2 & 18.6 \\
\hline 1972 & -4.5 & -2.9 & -1.6 & -13.2 & India & -3.6 & 27.6 & China & -3.4 & 26.0 & Thailand & -1.2 & 9.5 \\
\hline $1974^{1)}$ & -1.2 & -0.4 & -0.7 & -3.5 & India & -4.5 & 129.1 & Thailand & -0.8 & 23.5 & Cambodia & -0.5 & 14.8 \\
\hline 1976 & -3.6 & -3.2 & -0.3 & -11.5 & India & -8.1 & 70.0 & China & -2.2 & 18.6 & Japan & -0.9 & 8.1 \\
\hline 1979 & -3.3 & -1.6 & -1.7 & -11.4 & India & -13.2 & 115.4 & Indonesia & -1.3 & 11.2 & Myanmar & -1.1 & 9.9 \\
\hline 1982 & -2.2 & 0.4 & -2.5 & -8.5 & India & -10.9 & 128.1 & Thailand & -1.4 & 16.6 & Nepal & -0.6 & 7.4 \\
\hline 1987 & -4.0 & -0.9 & -3.1 & -17.6 & India & -12.4 & 70.5 & Viet Nam & -1.5 & 8.5 & Thailand & -1.5 & 8.3 \\
\hline 2002 & -3.9 & -1.8 & -2.2 & -21.1 & India & -18.8 & 89.1 & China & -1.3 & 6.2 & Myanmar & -0.8 & 3.9 \\
\hline 2003 & -2.1 & -0.5 & -1.5 & -11.2 & China & -13.8 & 123.7 & Japan & -1.1 & 10.3 & Myanmar & -0.8 & 6.7 \\
\hline
\end{tabular}

1) Although the deviation rate of rice production in monsoon Asia was not so small (more than -2 \%), the year was selected as a lean year based on Fig. (1).

produced the largest amount of rice but showed the smallest MADR. India is the second largest country of rice production, of which variability is relatively large. Cluster analysis applied to trend of deviation rate of rice production in each country showed as in Fig. (2). Although there are some exceptions, e.x. China and Indonesia, countries located similar area tend to belong to the same cluster.

Rice production in monsoon Asia decreased more than 2 $\%$ (the deviation is smaller than $-2 \%$ ) on nine occasions between 1963 and 2005 (Fig. 1a, Table 2). Fig. (1a) shows that production in 1974 was impacted by a poor harvest. However, the deviation was $1.2 \%$, of which a relatively small fraction may have been caused by the poor harvests in 1972 and 1976 (the 5-year running average in 1974 was small). Thus, the values from 1974 are also listed in Table 2. We refer to the 10 years presented in Table $\mathbf{2}$ as the lean years hereafter.

The poor harvests in the lean years were mostly associated with depleted yields until 1976 but were more closely associated with harvested area after 1982. These trends correspond to the pattern displayed by the coefficients of variance in Fig. (1b). Eight of the 10 lean years were connected with the lean harvest in India, indicating that production variability in India is the determining factor that impacts the productivity of all of the countries represented by monsoon Asia. In 1972, a lean harvest characterised all of monsoon Asia. Only two countries, Pakistan and Vietnam, exhibited positive values for the deviation rate of production in the year, but these were under $1 \%$. The lean harvest in 2003 was linked with production in East Asia. Although South Korea is not shown in Table 2 , the deviation of production was -0.6 million tonnes in 2003 (the 4th worst of any country).

Since China and India are the two largest producers of rice, the simultaneous occurrence of extremely poor production in both China and India will always drastically affect food security in monsoon Asia. However, the relationship between deviations in rice production in China and India shows that such cases are rare (Fig. 3). Notably, when the deviation in Chinese rice production was less than -5 million tonnes, India tended to experience a bumper harvest. Therefore, China is listed relatively few times in Table $\mathbf{2}$ (China is listed 4 times; Thailand, Myanmar and Japan are listed 5, 4 and 3 times, respectively).

\subsection{Relationship between the Production Variability and Meteorological Indexes}

One of the main causes of rice production variability is climate variability. In the case of monsoon Asia, climate is influenced by factors such as the El Niño Southern Oscillation (ENSO) and by Asian monsoons. ENSO is known to have caused disasters all around the world, and associates rice production in tropical Asia [1, 20, 21] and the international rice market [22]. Four of the 10 lean years studied here occurred during El Niño years, namely 1965, 1972, 1982, and 1987. The other lean years, except 1974, were also associated with El Niño: the ENSO index was $>0.5$ for $<6$ months a year. The year 1974 was between La Niña years; the ENSO index was <-0.5 from January to May. Rice production variability was also correlated with the strength of the Asian monsoons. The deviation of rice production was 


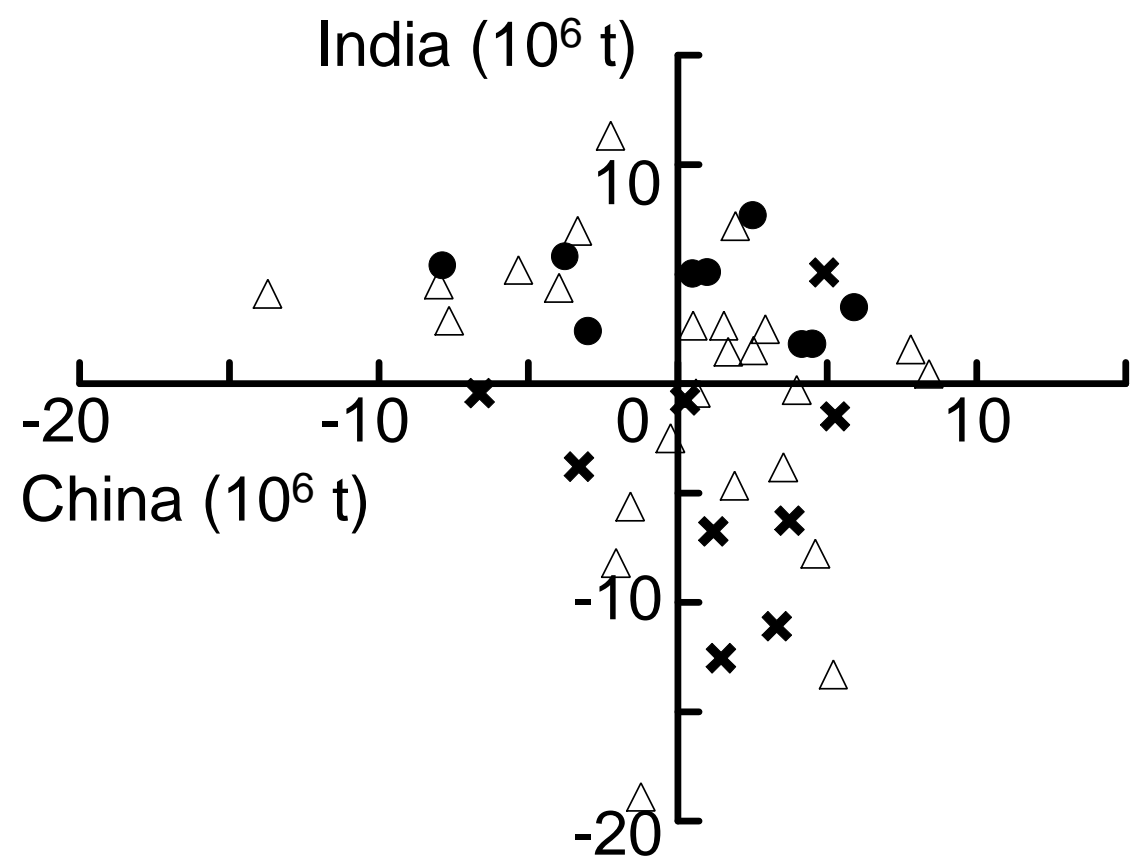

Fig. (3). Relationship between China and India with regard to the deviation of rice production as compared to the 5-year average. Symbols denote El Niño year (cross); neutral year (triangle); and La Niña year (circle).

significantly correlated with certain monsoon indexes: the Webster and Yang monsoon Index (WYI; $r=0.56$ ), the Indian summer Monsoon Index (IMI; $r=0.59)$, the Meridional Thermal Gradient Index (MTGI; $r=0.66$ ) and South Asian Summer Monsoon Index (SASMI; $r=0.57$ ), but not with the Western North Pacific Monsoon Index (WNPMI; $r=-0.04$ ) or the East Asian Summer Monsoon Index (EASMI; $r=$ $0.08)$.

The close association between rice production in monsoon Asia and ENSO and monsoon indexes is linked with variability of rice production in India. The correlation coefficient between the deviation of rice production in monsoon Asia and that in India is 0.78 , and rice production in India is strongly affected by ENSO and monsoon strength [1, 23]. El Niño years tend to be lean, while La Niña years tend to be bumper years (Fig. 3). The deviations in rice production varied significantly between El Niño and La Niña years $(\mathrm{P}<0.01$, Tukey-Kramer's test). Strong monsoons tend to cause bumper years in India, while weak monsoons result in lean years. The deviation rate of rice production in India was closely related to WYI $(\mathrm{r}=0.56)$, IMI $(\mathrm{r}=0.65)$, MTGI $(\mathrm{r}=$ $0.58)$ and SASMI $(r=0.62)$ but was not significantly associated with WNPMI $(\mathrm{r}=-0.05)$ or EASMI $(\mathrm{r}=-0.03)$. These associations are due to the relationship between precipitation and ENSO [24] or monsoon strength [9], since rice production in India is closely associated with precipitation [23].

On the other hand, there is no significant connection between rice production in China and ENSO or monsoon indexes. Even two-way analysis of variance (e.g., ENSO and classification of EASMI) failed to detect significant differences. Analysis of precipitation indicated that Hailar $\left(49^{\circ} 13-\right.$ 'N, 119 $\left.44^{\prime} \mathrm{E}\right)$ and Hami $\left(42^{\circ} 49^{\prime} \mathrm{N}, 9^{\circ} 31^{\prime} \mathrm{E}\right)$ had significantly larger precipitation in bumper year, and that Qiqihar $\left(47^{\circ} 23^{\prime} \mathrm{N}, \quad 123^{\circ} 55^{\prime} \mathrm{E}\right)$, Yining (435ำ $\left.\mathrm{N}, 81^{\circ} 19^{\prime} \mathrm{E}\right)$ and
Ruoqiang (39 $\left.02^{\prime} \mathrm{N}, 88^{\circ} 10^{\prime} \mathrm{E}\right)$ had significantly larger precipitation in lean year. However, these significantly different precipitations might not largely affect rice production in China. Comparisons of the precipitation anomalies in China also showed that the distribution of precipitation was similar between bumper and lean years: there tended to be less precipitation in East and South Central China (Fig. 4). The greatest difference in precipitation was observed in Southwest China, which saw more precipitation in bumper years and less in lean years.

Although previous studies indicated that relationship between some monsoon indexes and precipitations in China (e.g. [12]), trials to analyse the relationships between rice production in China and ENSO or monsoon indexes have not yet been identified a clear trend [2]. One of the reasons behind this difficulty is the variability in climate zone and production risk in China [25]. Statistical analysis and the comparison of precipitation anomalies in Fig. (4) also suggest the difficulty of analysing rice production based on precipitation. However, Fig. (4) suggests the following: (1) the reduced levels of precipitation in South Central and East China indicate more solar radiation in one of the major rice production regions; (2) since the upstream region of the Yangzi River is in Southwest China, precipitation in the region governs the water supply to South Central and East China; (3) less precipitation in South Central and East China, as well as Southwest China, causes poor harvests due to water shortages; (4) less precipitation in South Central and East China and more precipitation in Southwest China causes bumper harvests due to increased solar radiation and the supply of more water to South Central and East China. In order to prove our hypothesis, it was necessary to analyse the relationships between solar radiation, water supply and rice yield, and to analyse weather patterns and water movement 


\section{(a) Bumper year}

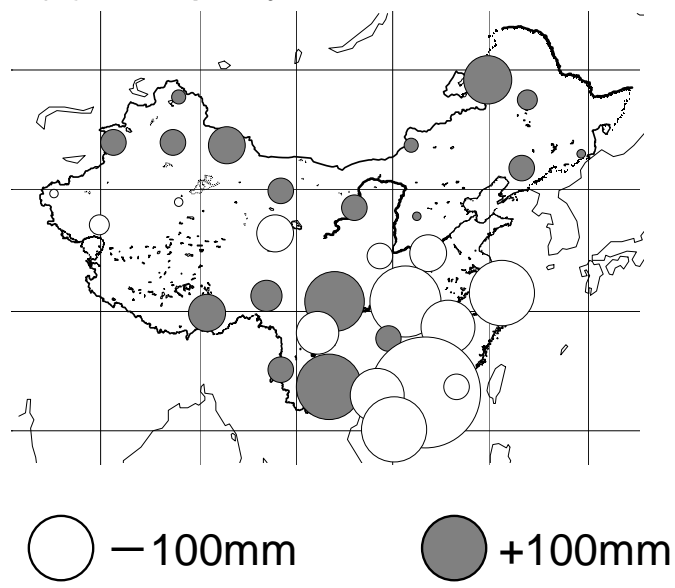

(b) Lean year

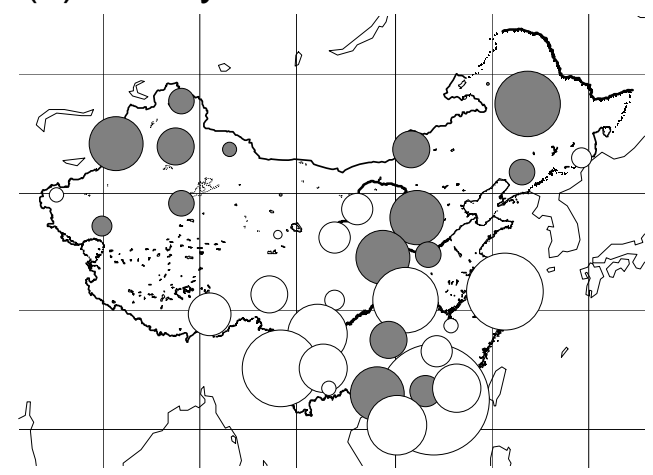

Fig. (4). Precipitation anomalies in bumper (a) and lean (b) years, based on the 47-year average from 1961 to 2007. Bumper year values are averaged among 1966, 1970, 1979, 1984 and 1990; lean year values are averaged among 1969, 1981, 1988, 1994 and 2003.

from the upstream river region to the rice paddies. Simulation modelling is one of the preferred methods for this purpose $[26,27]$. If the hypothesis holds true, climatological analysis of the distribution of precipitation anomalies in China and its relation to the distribution in India would be the next step.

\section{CONCLUSION}

We analyzed the variability of rice production in monsoon Asia, and revealed that the past lean years mostly derived from India. When the largest producer of rice, China, had extremely poor harvest, the 2nd largest producer, India, tended to have bumper harvest. It is important to determine whether this relationship is the result of causation or only fortuity in order to develop the strategy for food security. Since any climatologic connection was not found between rice production in India and that in China by the casual analysis in this study, more accurate analyses which use approaches from disciplines such as climatology, hydrology and agronomy are necessary.

\section{CONFLICT OF INTEREST}

The authors confirm that this article content has no conflict of interest.

\section{ACKNOWLEDGEMENTS}

We thank Y. Kajikawa, B. Wang, J. Li and R. Kawamura for their online list of monsoon indexes. This work was partly supported by a Grant-in-Aid for Scientific Research (No. 13575018) from the Japan Society for the Promotion of Science, by Environmental Research and Technology Development Fund, Ministry of the Environment, Japan (E1104) and by Green network of Excellence-environmental
Information (GRENE-ei) from the Ministry of Education, Culture, Sports, Science and Technology (MEXT) of Japan.

\section{REFERENCES}

[1] Selvaraju R. Impact of El Nino-southern oscillation on Indian foodgrain production. Int J Climatol 2003; 23: 187-206.

[2] Tao F, Yokozawa M, Zhang Z, Hayashi Y, Grassl H, Fu C. Variability in climatology and agricultural production in China in association with the East Asian summer monsoon and El Niño Southern Oscillation. Clim Res 2004; 28: 23-30.

[3] Kawatsu S, Homma K, Horie T, Shiraiwa T. Change of weather condition and its effect on rice production during the past 40 years in Japan. Jpn J Crop Sci 2007; 76: 423-432.

[4] FAO. FAOSTAT. 2012;

Available at: http://faostat.fao.org/default.aspx

[5] Dawe D. The rice crisis: Markets, policies and food security. FAO, Roma. 2010.

[6] Japan Meteorological Agency. El Niño monitoring and outlook. 2012;

Available at: http://ds.data.jma.go.jp/gmd/tcc/tcc/products/elnino/index.html

[7] Webster PJ, Yang S. Monsoon and ENSO: Selectively interactive systems. Quart J Roy Meteor Soc 1992; 118: 877-926.

[8] Wang B, Fan Z. Choice of South Asian summer monsoon indices. Bull Amer Meteor Soc 1999; 80: 629-638.

[9] Wang B, Wu R, Lau KM. Interannual variability of Asian summer monsoon: Contrast between the Indian and western North PacificEast Asian monsoons. J Climate 2001; 14: 4073-4090.

[10] Kajikawa Y, Wang B. Monsoon monitoring page. 2012; Available at: http://iprc.soest.hawaii.edu/ ykaji/monsoon/index.html

[11] Li J, Zeng Q. A new monsoon index and the geographical distribution of the global monsoons. Adv Atmos Sci 2003; 20: 299-302.

[12] Li J, Zeng Q. A unified monsoon index. Geophys Res Lett 2002; 29: $1274-1278$

[13] Li J. Jianping Li's home page 2012; Available at: http://ljp.lasg.ac.cn/dct/page/65544

[14] Kawamura R. A possible mechanism of the Asian summer monsoon-ENSO coupling. J Meteor Soc Japan 1998; 76: 1009-1027.

[15] Miyakoda K, Kinter III JL, Yang S. The role of ENSO in the south Asian monsoon and pre-monsoon signals over the Tibetan Plateau. J Meteor Soc Japan 2003; 81: 1015-1039. 
[16] Kawamura R. Asian Summer Monsoon Index. 2012; Available at: http://www.sci.u-toyama.ac.jp/ earth/j-kawamura/data/data1.html

[17] National Climatic Data Center, USA. GHCN-Monthly Version 2. 2009; Available at: http:// www.ncdc.noaa.gov /oa/climate/ghenmonthly/index.php

[18] Penning de Vries FWT. Food security? We are losing ground fast! In: Nösberger J, Geiger HH, Struik PC, Eds. Crop science: Progress and prospects. CABI Publishing, Wallingford. 2000; pp 1-14.

[19] Suzuki K, Goto A. Analysis of stability of rainfed rice cultivation in Northeast Thailand. Southeast Asian Studies 1999; 37: 50-64.

[20] Dawe D, Moya P, Valencia S. Institutional, policy and farmer responses to drought: El Niño events and rice in the Philippines. Disasters 2009; 33: 291-307.

[21] Keil A, Zeller M, Wida A, Sanim B, Birner R. What determines farmers' resilience towards ENSO-related drought? An empirical assessment in Central Sulawesi, Indonesia. Climatic Change 2008; 86: 291-307.
[22] Chen CC, McCarl BA, Chang CC. Strong El Niño-Southern Oscillation events and the economics of the international rice market. Clim Res 2008; 36: 113-122.

[23] Krishna Kumar K, Rupa Kumar K, Ashrit RG, Deshpande NR, Hansen JW. Climate impacts on Indian agriculture. Int J Climatol 2004; 24: 1375-1393.

[24] Ropelewski CF, Halpert MS. Global and regional scale precipitation associated with ENSO. Mon Wea Rev 1987; 115: 1606-1626.

[25] Qian W, Zhu Y. Climate change in China from 1880 to 1998 and its impact on the environmental condition. Climatic Change 2001; 50: 419-444.

[26] Tsujimoto K, Homma K, Koike T, Ohta T. (2013) Development of a coupled model of a distributed hydrological model and a rice growth model for grasping necessary information for rain-fed agriculture. J Jpn Soc Civil Engineers Ser B1 2013; 69: 511-516.

[27] Yoshida K, Azechi I, Hariya R, et al. Future water use in Asia monsoon region: A case study in Indonesia. J Develop Sustain Agric $2013 ; 8: 25-31$

Received: April 18, 2014

Revised: June 28, 2014

Accepted: June 30, 2014

(C) Homma et al.; Licensee Bentham Open.

This is an open access article licensed under the terms of the Creative Commons Attribution Non-Commercial License (http://creativecommons.org/licenses/by-nc/3.0/) which permits unrestricted, non-commercial use, distribution and reproduction in any medium, provided the work is properly cited. 